\title{
Low Bone Mineral Density in Middle-Aged Breast Cancer Survivors: Prevalence and Associated Factors
}

\author{
Délio Marques Conde ${ }^{a}$ Lúcia Costa-Paiva $^{b}$ \\ Edson Zangiacomi Martinez ${ }^{c}$ Aarão Mendes Pinto-Neto ${ }^{b}$ \\ aBreast Service, Hospital for Maternal and Child Healthcare, Goiânia, \\ bDepartment of Gynecology and Obstetrics, University of Campinas, \\ 'Department of Social Medicine, São Paulo University, Ribeirão Preto, Brazil
}

\section{Keywords}

Breast cancer - Menopause - Bone mass - Osteoporosis . Middle-aged women

\section{Summary}

Background: The aim of this study was to investigate the prevalence of low bone mineral density (BMD) and associated factors in middle-aged breast cancer survivors (BCS). Patients and Methods: A cross-sectional study was conducted with 70 BCS of 45-65 years of age undergoing complete oncology treatment. Logistic regression models were used to identify factors associated with low BMD (osteopenia and osteoporosis taken together as a single group). Results: The mean age of participants was $53.2 \pm 5.9$ years. BMD was low at the femoral neck in $28.6 \%$ of patients and at the lumbar spine in $45.7 \%$. Body mass index $\leq 30 \mathrm{~kg} / \mathrm{m}^{2}$ (adjusted odds ratio (OR) 3.43; 95\% confidence interval (Cl) 1.0-11.3) and postmenopausal status (OR adjusted 20.42; 95\% Cl 2.0-201.2) were associated with low BMD at the lumbar spine. Femoral neck measurements, age $>50$ years (OR $3.41 ; 95 \% \mathrm{Cl}$ 1.0-11.6), and time since diagnosis $>50$ months (OR adjusted 3.34; $95 \% \mathrm{Cl} 1.0-11.3$ ) increased the likelihood of low BMD. Conclusion: These findings show that low BMD is common in middle-aged BCS. Factors were identified that may affect BMD in BCS and should be considered when implementing strategies to minimize bone loss in middle-aged women with breast cancer.

\section{Schlüsselwörter}

Mammakarzinom - Menopause $\cdot$ Knochenmasse .

Osteoporose · Frauen mittleren Alters

\section{Zusammenfassung}

Hintergrund: Ziel dieser Studie war die Bestimmung der Prävalenz niedriger Knochendichte und damit assoziierter Faktoren bei Brustkrebsüberlebenden mittleren Alters. Patienten und Methoden: Es wurde eine Querschnittsstudie mit 70 Brustkrebsüberlebenden im Alter von 45 bis 65 Jahren, die in kompletter onkologischer Behandlung waren, durchgeführt. Mit niedriger Knochendichte assoziierte Faktoren wurden mit logistischen Regressionsmodellen ermittelt (Osteopenie und Osteoporose wurden zu einer Gruppe zusammengefasst). Ergebnisse: Das mittlere Alter der Teilnehmer war 53,2 \pm 5,9 Jahre. Eine niedrige Knochendichte bestand am Oberschenkelhals bei $28,6 \%$ der Patienten und im Lendenwirbelbereich bei $45,7 \%$. Body mass index $\leq 30 \mathrm{~kg} / \mathrm{m}^{2}$ (adjustierte Odds-Ratio (OR) 3,43; 95\% Konfidenzinterval (KI) 1,0-11,3) und postmenopausaler Status (OR adjustiert 20,42; 95\% KI 2,0-201,2) waren mit einer niedrigen Knochendichte im Lendenwirbelbereich assoziiert. Umfang des Oberschenkelhalses, Alter $>50$ Jahre (OR 3,41; $95 \%$ KI 1,0-11,6) sowie Zeit seit Diagnosestellung > 50 Monate (OR adjustiert 3,34; 95\% KI 1,0-11,3) machten eine niedrige Knochendichte wahrscheinlicher. Schlussfolgerung: Diese Ergebnisse zeigen, dass niedrige Knochendichte bei Brustkrebsüberlebenden mittleren Alters häufig vorkommt. Es konnten Faktoren identifiziert werden, die die Knochendichte bei dieser Patientengruppe potentiell beeinflussen und bei der Implementierung von Strategien zur Minimierung des Knochenverlustes bei Brustkrebspatientinnen mittleren Alters berücksichtigt werden sollten.

\section{KARGER \\ Fax +497614520714 \\ Information@Karger.de}

www.karger.com (c) 2012 S. Karger GmbH, Freiburg

$1661-3791 / 12 / 0072-0121 \$ 38.00 / 0$

Accessible online at:

www.karger.com/brc
Délio Marques Conde, MD

Hospital for Maternal and Child Healthcare, Breast Service

Rua R-7 com Av. Perimetral, S/N, St. Oeste

74125-120 Goiânia, GO, Brazil

Tel./Fax +55 6232096151

delioconde@bol.com.br 


\section{Introduction}

Breast cancer is the most common malignancy in women worldwide [1]. Women aged $45-64$ years account for $47 \%$ of new breast cancer cases in the United States [2]. A large proportion of women will be diagnosed with breast cancer during the menopausal transition or in the postmenopause, stages characterized by changes in reproductive hormones [3]. In breast cancer survivors (BCS), ovarian failure resulting from chemotherapy or the reproductive aging process [3] is associated with decreased bone density [4]. Breast cancer patients $>40$ years of age are more likely to develop amenorrhea after chemotherapy than younger women $[4,5]$, with rapid bone loss $[4,6]$. Bone loss starts to accelerate 2 years before the last menstruation, with a significant loss in the 2 years after menopause [7]. Current guidelines recommend that hormone therapy should be considered in women with established bone loss to prevent further reduction in bone mineral density (BMD) and decrease osteoporotic fractures [8]. Despite its effects on bone, hormone therapy increases the risk of recurrence in BCS [9]. BMD has previously been investigated in BCS [4-6, 10-13]. Some authors have reported an association between chemotherapy-induced ovarian failure and bone loss $[4,6]$. Others have suggested that a decrease in BMD may occur in BCS undergoing chemotherapy irrespective of the effect of chemotherapy on ovarian function [5]. Osteoclastic activity may increase from the breast cancer itself, enhancing bone resorption [14]. Other factors that may damage bone health include the use of aromatase inhibitors [15] and secondary causes such as vitamin D deficiency and hyperparathyroidism [16]. A combination of factors may contribute to bone loss, leading to a greater fracture risk in BCS [17]. The frequency of abnormal BMD may vary according to the skeletal site [5, $10,11,18]$. In a follow-up study of postmenopausal women, a greater reduction in BMD was observed at the lumbar spine than at the femoral neck [18]. As in healthy women [19, 20], BMD in BCS may be affected by menopausal status [6], body mass index (BMI) and weight [6, 10-13]. Most studies investigating $\mathrm{BMD}$ in $\mathrm{BCS}$ were conducted in developed countries [4-6, 10-13]. The aim of the present study was to investigate the prevalence of low BMD in middle-aged women with breast cancer and its associated factors.

\section{Patients and Methods}

\section{Patients}

A complete description of the participant selection process has been published previously [21]. Briefly, the current sample originated from a study conducted to investigate the prevalence of menopausal symptoms, quality of life, and BMD in middle-aged BCS [21]. A cross-sectional study was conducted at the Women's Hospital, University of Campinas, Brazil. Women of 45-65 years of age, who had not used hormone therapy or tamoxifen in the previous 6 months and had no history of other malignant tumors, were included in the study. None of the participants was taking aromatase inhibitors. $100 \mathrm{BCS}$ were consecutively invited to participate in the study. 3 patients refused due to lack of time. 22 patients were undergoing oncology treatment, and 5 had no BMD measurements. 70 BCS comprised the present study sample. Participants provided information on their sociodemographic characteristics. Clinical characteristics included BMI $\left(\mathrm{kg} / \mathrm{m}^{2}\right)$, time since breast cancer diagnosis, tumor stage, chemotherapy, radiotherapy, diabetes mellitus, and hypertension. Study approval was obtained from the institution's internal review board, and all women signed an informed consent form

\section{Bone Mineral Density Measurement}

BMD $\left(\mathrm{g} / \mathrm{cm}^{2}\right)$ was measured at the femoral neck and lumbar spine (L2L4) using a Lunar DPX device (DXA, Madison, WI, USA). BMD was also expressed as T-scores, using the World Health Organization criteria [22]: normal: T-score $\geq-1$ standard deviation (SD); osteopenia: T-score between -1 and $-2.5 \mathrm{SD}$; and osteoporosis: T-score $\leq-2.5 \mathrm{SD}$. A BMD $\mathrm{T}$-score $<-1 \mathrm{SD}$ was considered low.

\section{Statistical Analysis}

The relationship between the characteristics of the breast cancer patients and BMD, classified as low or normal, was assessed using logistic regression models [23], calculating the crude and adjusted (for age and BMI) odds ratio (OR) as measures of association, with the respective $95 \%$ confidence intervals (95\% CI). SAS version 9.2 (SAS Institute Inc., Cary, $\mathrm{NC}$, USA) was used to perform all statistical analysis.

\section{Results}

The mean age of the participants was $53.2 \pm 5.9$ years. Mean time since breast cancer diagnosis was $65.2 \pm 55.1$ months. Approximately $74 \%$ of participants were white, $82.9 \%$ were postmenopausal, and $11.4 \%$ were smokers. The prevalence of diabetes mellitus and hypertension was 10 and $25.7 \%$, respectively. Distribution according to tumor stage was: $0(11.4 \%)$, I $(17.1 \%)$, II (52.9\%), and III (18.6\%). Approximately $73 \%$ had undergone chemotherapy, while $70 \%$ had been submitted to radiotherapy. Mean BMD $\left(\mathrm{g} / \mathrm{cm}^{2}\right)$ was $0.930 \pm 0.139$ at the femoral neck and $1.090 \pm 0.147$ at the lumbar spine (L2L4). The prevalence of low BMD was $28.6 \%$ at the femoral neck and $45.7 \%$ at the lumbar spine (L2-L4) (table 1). BMI $\leq 30 \mathrm{~kg} / \mathrm{m}^{2}$ (OR adjusted 3.43; 95\% CI 1.0-11.3) and postmenopausal status (OR adjusted 20.42; 95\% CI 2.0-201.2) increased the risk of low BMD at the lumbar spine (L2-L4) (table 2). Age $>50$ years (OR 3.41; 95\% CI 1.0-11.6) and time since diagnosis > 50 months (OR adjusted 3.34; $95 \%$ CI 1.0 11.3) were factors associated with low BMD at the femoral neck (table 3).

\section{Discussion}

Low BMD was associated with a 1.80-4.0-fold increase in fracture rate [19]. Our findings suggest that middle-aged BCS are at an increased risk of fracture. Similarly, in the Women's Health Initiative Observational Study, fracture risk was found to be $15 \%$ higher in BCS compared to cancer-free women [17]. In the present study, mean BMD $\left(\mathrm{g} / \mathrm{cm}^{2}\right)$ was 0.930 
Table 1. Prevalence of low bone mineral density in breast cancer survivors according to $\mathrm{T}$-score $(\mathrm{n}=70)$

\begin{tabular}{lllll}
\hline \multirow{2}{*}{ Site } & \multicolumn{3}{l}{ Patients, n (\%) } & \\
\cline { 2 - 5 } & normal BMD & low BMD $^{\text {a }}$ & osteopenia & osteoporosis \\
\hline Femoral neck & $50(71.4)$ & $20(28.6)$ & $18(25.7)$ & $2(2.8)$ \\
Lumbar spine (L2-L4) & $38(54.3)$ & $32(45.7)$ & $23(32.8)$ & $9(12.8)$
\end{tabular}

${ }^{\text {a }}$ T-score $<-1 \mathrm{SD}$ (osteopenia + osteoporosis).

$\mathrm{BMD}=$ Bone mineral density.

Table 2. Factors associated with low bone mineral density at the lumbar spine of breast cancer survivors according to $\mathrm{T}$-score $(\mathrm{n}=70)$

\begin{tabular}{|c|c|c|c|c|c|c|}
\hline \multirow[t]{2}{*}{ Characteristics } & \multicolumn{2}{|c|}{ Bone mineral density, n (\%) } & \multicolumn{2}{|l|}{ Crude } & \multicolumn{2}{|c|}{ Adjusted } \\
\hline & low & normal & OR & $95 \% \mathrm{CI}$ & OR & $95 \% \mathrm{CI}$ \\
\hline \multicolumn{7}{|l|}{ Age, years } \\
\hline$\leq 50$ & $12(38)$ & $15(39)$ & ref. & & & \\
\hline$>50$ & $20(63)$ & $23(61)$ & 1.09 & $0.4-2.9$ & - & - \\
\hline \multicolumn{7}{|l|}{ Race $^{\mathrm{a}}$} \\
\hline White & $26(81)$ & $26(68)$ & ref. & & ref. & \\
\hline Non-white & $6(19)$ & $12(32)$ & 0.50 & $0.1-1.5$ & 0.55 & $0.1-1.8$ \\
\hline \multicolumn{7}{|c|}{ Age at menarche ${ }^{\mathrm{a}}$, years } \\
\hline$>12$ & $21(66)$ & $19(50)$ & ref. & & ref. & \\
\hline$\leq 12$ & $11(34)$ & $19(50)$ & 0.52 & $0.1-1.4$ & 0.51 & $0.1-1.4$ \\
\hline \multicolumn{7}{|c|}{ Body mass index ${ }^{\mathrm{b}}, \mathrm{kg} / \mathrm{m}^{2}$} \\
\hline$>30$ & $5(16)$ & $14(37)$ & ref. & & ref. & \\
\hline$\leq 30$ & $27(84)$ & $24(63)$ & 3.15 & $1.0-10.0$ & 3.43 & $1.0-11.3$ \\
\hline \multicolumn{7}{|l|}{ Menopausal status ${ }^{\mathrm{a}}$} \\
\hline Premenopausal & $1(3)$ & $11(29)$ & ref. & & ref. & \\
\hline Postmenopausal & $31(97)$ & $27(71)$ & 12.63 & $1.5-104.3$ & 20.42 & $2.0-201.2$ \\
\hline \multicolumn{7}{|l|}{ Parity $^{\mathrm{a}}$} \\
\hline 0 & $4(13)$ & 7 (18) & ref. & & ref. & \\
\hline$\geq 1$ & $28(88)$ & $31(82)$ & 1.58 & $0.4-6.0$ & 1.59 & $0.4-6.3$ \\
\hline \multicolumn{7}{|l|}{ Smoking ${ }^{\mathrm{a}}$} \\
\hline No & $27(84)$ & $35(92)$ & ref. & & ref. & \\
\hline Yes & $5(16)$ & $3(8)$ & 2.16 & $0.4-9.9$ & 1.84 & $0.3-8.7$ \\
\hline \multicolumn{7}{|c|}{ Time since diagnosis, months $\mathrm{s}^{\mathrm{a}}$} \\
\hline$\leq 50$ & $13(41)$ & $22(58)$ & ref. & & ref. & \\
\hline$>50$ & $19(59)$ & $16(42)$ & 2.01 & $0.7-5.2$ & 1.71 & $0.6-4.7$ \\
\hline \multicolumn{7}{|l|}{ Hypertension $^{\mathrm{a}}$} \\
\hline No & $27(84)$ & $25(66)$ & ref. & & ref. & \\
\hline Yes & $5(16)$ & $13(34)$ & 0.36 & $0.1-1.1$ & 0.50 & $0.1-1.8$ \\
\hline \multicolumn{7}{|l|}{ Diabetes $^{\mathrm{a}}$} \\
\hline No & $29(91)$ & $34(89)$ & ref. & & ref. & \\
\hline Yes & $3(9)$ & $4(11)$ & 0.88 & $0.1-4.2$ & 1.60 & $0.2-9.5$ \\
\hline \multicolumn{7}{|l|}{ Chemotherapy $^{\mathrm{a}}$} \\
\hline No & $12(38)$ & 7 (18) & ref. & & ref. & \\
\hline Yes & $20(63)$ & $31(82)$ & 0.38 & $0.1-1.1$ & 0.41 & $0.1-1.3$ \\
\hline \multicolumn{7}{|l|}{ Radiotherapy $^{\mathrm{a}}$} \\
\hline No & $9(28)$ & $12(32)$ & ref. & & ref. & \\
\hline Yes & $23(72)$ & $26(68)$ & 1.18 & $0.4-3.3$ & 1.04 & $0.3-3.1$ \\
\hline
\end{tabular}

${ }^{\mathrm{a} O R}$ adjusted for age and body mass index.

${ }^{\mathrm{b}} \mathrm{OR}$ ajusted for age.

OR = Odds ratio; $95 \% \mathrm{CI}=95 \%$ confidence interval; ref. $=$ reference

\pm 0.139 at the femoral neck and $1.090 \pm 0.147$ at the lumbar spine. An investigation of healthy Brazilian women (mean age 53.9 years) showed a mean BMD $\left(\mathrm{g} / \mathrm{cm}^{2}\right)$ of $0.912 \pm 0.151$ at the femoral neck and $1.069 \pm 0.177$ at the lumbar spine [24], values very close to those found in this cohort of BCS. In this study, the prevalence of osteopenia and osteoporosis was 25.7 and $2.8 \%$, respectively, at the femoral neck. According to lumbar spine measurements, $32.8 \%$ of the participants had osteopenia and $12.8 \%$ had osteoporosis. In a study of postmenopausal BCS, Twiss et al. [11] reported that $16.5 \%$ had osteopenia and $2.4 \%$ had osteoporosis according to total hip measurement. The same authors also found that $27.3 \%$ had osteopenia and $10.8 \%$ had osteoporosis at the lumbar spine
[11]. Those results are consistent with the present data regarding a higher prevalence of changes at the lumbar spine. Low BMD may be more prevalent at the lumbar spine because the trabecular bone which forms a major part of the vertebral body is highly responsive to hormonal alterations [17] common in the age group evaluated in the present study.

Various authors have identified a positive relationship between higher BMI and bone mass both in BCS [6, 10-13] and cancer-free women [18-20]. Waltman et al. [12] reported BMD findings in $249 \mathrm{BCS}$. These authors identified an association between higher BMI and greater BMD at the spine. These results confirm the findings of the present study and are consistent with results from other studies conducted with 
Table 3. Factors associated with low bone mineral density at the femoral neck of breast cancer survivors according to $\mathrm{T}$-score $(\mathrm{n}=70)$

\begin{tabular}{|c|c|c|c|c|c|c|}
\hline \multirow[t]{2}{*}{ Characteristics } & \multicolumn{2}{|c|}{ Bone mineral density, n (\%) } & \multicolumn{2}{|c|}{ Crude } & \multicolumn{2}{|c|}{ Adjusted } \\
\hline & low & normal & OR & $95 \% \mathrm{CI}$ & OR & $95 \% \mathrm{CI}$ \\
\hline \multicolumn{7}{|l|}{ Age, years } \\
\hline$\leq 50$ & $4(20)$ & $23(46)$ & ref. & & & \\
\hline$>50$ & $16(80)$ & $27(54)$ & 3.41 & $1.0-11.6$ & - & - \\
\hline \multicolumn{7}{|l|}{ Race $^{\mathrm{a}}$} \\
\hline White & $15(75)$ & $37(74)$ & ref. & & ref. & \\
\hline Non-white & $5(25)$ & $13(26)$ & 0.95 & $0.2-3.1$ & 1.01 & $0.28-3.7$ \\
\hline$>12$ & $10(50)$ & $30(60)$ & ref. & & ref. & \\
\hline$\leq 12$ & $10(50)$ & $20(40)$ & 1.50 & $0.5-4.3$ & 1.79 & $0.5-5.5$ \\
\hline \multicolumn{7}{|c|}{ Body mass index ${ }^{\mathrm{b}}, \mathrm{kg} / \mathrm{m}^{2}$} \\
\hline$>30$ & $3(15)$ & $16(32)$ & ref. & & ref. & \\
\hline$\leq 30$ & $17(85)$ & $34(68)$ & 2.67 & $0.6-10.4$ & 3.87 & $0.9-16.1$ \\
\hline \multicolumn{7}{|l|}{ Menopausal status ${ }^{a}$} \\
\hline Premenopausal & $1(5)$ & $11(22)$ & ref. & & ref. & \\
\hline Postmenopausal & $19(95)$ & $39(78)$ & 5.36 & $0.6-44.6$ & 2.73 & $0.2-27.0$ \\
\hline$\geq 1$ & $18(90)$ & $41(82)$ & 1.98 & $0.3-10.1$ & 1.94 & $0.3-10.8$ \\
\hline \multicolumn{7}{|l|}{ Smoking $^{\mathrm{a}}$} \\
\hline No & $18(90)$ & $44(88)$ & ref. & & ref. & \\
\hline Yes & $2(10)$ & $6(12)$ & 0.81 & $0.1-4.4$ & 0.64 & $0.1-3.8$ \\
\hline \multicolumn{7}{|c|}{ Time since diagnosis, months ${ }^{\mathrm{a}}$} \\
\hline$\leq 50$ & $5(25)$ & $30(60)$ & ref. & & ref. & \\
\hline$>50$ & $15(75)$ & $20(40)$ & 4.50 & $1.4-14.4$ & 3.34 & $1.0-11.3$ \\
\hline \multicolumn{7}{|l|}{ Hypertension $^{\mathrm{a}}$} \\
\hline No & $16(80)$ & $36(72)$ & ref. & & ref. & \\
\hline Yes & $4(20)$ & $14(28)$ & 0.64 & $0.1-2.3$ & 0.84 & $0.2-3.5$ \\
\hline \multicolumn{7}{|l|}{ Diabetes $^{\mathrm{a}}$} \\
\hline No & $19(95)$ & $44(88)$ & ref. & & ref. & \\
\hline Yes & $1(5)$ & $6(12)$ & 0.39 & $0.04-3.4$ & 0.49 & $0.04-5.1$ \\
\hline \multicolumn{7}{|l|}{ Chemotherapy $^{\mathrm{a}}$} \\
\hline No & $6(30)$ & $13(26)$ & ref. & & ref. & \\
\hline Yes & $14(70)$ & $37(74)$ & 0.82 & $0.2-2.6$ & 1.12 & $0.3-3.8$ \\
\hline \multicolumn{7}{|l|}{ Radiotherapy $^{\mathrm{a}}$} \\
\hline
\end{tabular}

${ }^{\mathrm{a} O R}$ adjusted for age and body mass index.

${ }^{\mathrm{b}} \mathrm{OR}$ adjusted for age.

OR = Odds ratio $; 95 \% \mathrm{CI}=95 \%$ confidence interval; ref. = reference

BCS $[6,10,11,13]$. The osteo-protective effect of BMI is unclear. However, osteo-protection is probably based on a complex combination of mechanical and hormonal factors, including the role of adiponectin in bone mass regulation [25].

Several studies have shown that postmenopausal status constitutes a risk factor for bone loss [6, 20]. Estrogen exerts a protective effect on bones and plays an important role in maintaining bone health [26]. A decrease in bone mass due to an imbalance between bone resorption and bone formation is typical of osteoporosis in women with estrogen depletion [26]. As found in cancer-free women [6,20], the results of the present study show that menopause increases the risk of low BMD in BCS.

In the present cohort, age $>50$ years was associated with low BMD. However, other studies found no relationship between age and BMD [10,12]. Age-related bone loss has been reported by other authors [18-20], confirming our findings. In a population-based study with a 15 -year follow-up that included 955 postmenopausal women, BMD was shown to decrease significantly at the femoral neck and lumbar spine [18].
The decline in BMD was greater at the lumbar spine $(-3.12 \%$ per year), than at the femoral neck $(-1.67 \%$ per year), suggesting that estrogen deficiency may act differently at different bone sites [18].

This case study showed an association between a longer time since diagnosis and low BMD. Another study evaluated BMD in 30 postmenopausal BCS with a mean of $61.7 \pm 42.1$ months since diagnosis; however, no association was found between time since diagnosis and BMD [10]. A longer time since diagnosis may imply older age. However, in the current study, analysis of the factors associated with low BMD was adjusted for age, minimizing the effect of the variable age.

The present study had some limitations due to its crosssectional design and lack of a healthy control group. Physical activity, medication, and calcium intake were not investigated. However, in a systematic review [27], evidence of an association between current physical activity or calcium intake and BMD was inconsistent. Factors associated with low BMD described in non-BCS (age, BMI, menopause) were identified, and also negatively affected BMD in BCS. Breast cancer 
treatment, ovarian failure, and contraindication to hormone therapy may intensify bone loss in midlife. The findings of this study may prove useful when establishing and implementing strategies to minimize bone loss in middle-aged BCS.

\section{Disclosure Statement}

The authors declare no conflict of interest

\section{References}

1 Jemal A, Bray F, Center MM, et al.: Global Cancer Statistics. CA Cancer J Clin 2011;61:69-90.

2 National Cancer Institute: SEER Cancer Statistics Review 1975-2008. Available at www.seer.cancer. gov/csr/1975_2008/results_merged/topic_age_dist.pdf; accessed April 30, 2011.

3 Soules MR, Sherman S, Parrott E, Rebar R, Santoro N, Utian W, Woods N: Executive summary: Stages of Reproductive Aging Workshop (STRAW) Park City, Utah, July, 2001. Menopause 2001;8:402-7.

4 Vehmanen L, Saarto T, Elomaa I, et al.: Long-term impact of chemotherapy-induced ovarian failure on bone mineral density (BMD) in premenopausal breast cancer patients. The effect of adjuvant clodronate treatment. Eur J Cancer 2001;37:2373-8.

$\checkmark 5$ Cameron DA, Douglas S, Brown JE, Anderson RA Bone mineral density loss during adjuvant chemotherapy in pre-menopausal women with early breast cancer: is it dependent on oestrogen deficiency? Breast Cancer Res Treat 2010;123:805-14.

6 Bruning PF, Pit MJ, de Jong-Bakker M, van den Ende A, Hart A, van Enk A: Bone mineral density after adjuvant chemotherapy for premenopausal breast cancer. Br J Cancer 1990;61:308-10.

7 Sowers MR, Zheng H, Jannausch ML, et al.: Amount of bone loss in relation to time around the final menstrual period and follicle-stimulating hormone staging of the transmenopause. J Clin Endocrinol Metab 2010;95:2155-62.

$\rightarrow 8$ The North American Menopause Society: Management of osteoporosis in postmenopausal women: 2010 position statement of The North American Menopause Society. Menopause 2010;17:25-54.

$\checkmark$ Kenemans P, Bundred NJ, Foidart JM, et al.: Safety and efficacy of tibolone in breast-cancer patients with vasomotor symptoms: a double-blind, randomised, non-inferiority trial. Lancet Onco 2009;10:135-46.
10 Twiss JJ, Waltman N, Ott CD, et al.: Bone mineral density in postmenopausal breast cancer survivors. J Am Acad Nurse Pract 2001;13:276-84.

11 Twiss JJ, Gross GJ, Waltman NL, Ott CD, Lindsey AM: Health behaviors in breast cancer survivors experiencing bone loss. J Am Acad Nurse Pract 2006;18:471-81.

12 Waltman NL, Ott CD, Twiss JJ, et al.: Bone mineral density and bone turnover in postmenopausal women treated for breast cancer. Cancer Nurs 2008;31:182-90.

13 Winters-Stone KM, Nail L, Bennett JA, Schwartz A: Bone health and falls: fracture risk in breast cancer survivors with chemotherapy-induced amenorrhea. Oncol Nurs Forum 2009;36:315-25.

14 Delmas PD, Fontana A: Bone loss induced by cancer treatment and its management. Eur J Cancer 1998;34:260-2.

15 Baum M, Budzar AU, Cuzick J, et al.: Anastrozole alone or in combination with tamoxifen versus tamoxifen alone for adjuvant treatment of postmenopausal women with early breast cancer: first results of the ATAC randomised trial. Lancet 2002:359:2131-9.

16 Mann GB, Kang YC, Brand C, Ebeling PR, Miller JA: Secondary causes of low bone mass in patients with breast cancer: a need for greater vigilance. J Clin Oncol 2009;27:3605-10.

17 Chen Z, Maricic M, Bassford TL, et al.: Fracture risk among breast cancer survivors: results from the Women's Health Initiative Observational Study. Arch Intern Med 2005;165:552-8.

18 Zhai G, Hart DJ, Valdes AM, et al.: Natural history and risk factors for bone loss in postmenopausal Caucasian women: a 15-year follow-up populationbased study. Osteoporos Int 2008;19:1211-7.
19 Siris ES, Miller PD, Barrett-Connor E, et al. Identification and fracture outcomes of undiagnosed low bone mineral density in postmenopausal women: results from the National Osteoporosis Risk Assessment. JAMA 2001;286:2815-22.

20 Nahas EA, Kawakami MS, Nahas-Neto J, et al.: Assessment of risk factors for low bone mineral density in Brazilian postmenopausal women. Climacteric 2011;14::220-7.

21 Conde DM, Pinto-Neto AM, Cabello C, et al. Quality of life in Brazilian breast cancer survivors age 45-65 years: associated factors. Breast J 2005;11:425-32.

22 Kanis JA: Assessment of fracture risk and its application to screening for postmenopausal osteoporosis: synopsis of a WHO report. WHO Study Group. Osteoporos Int 1994;4:368-81.

23 Hosmer DW, Lemeshow S: Applied Logistic Regression, 2nd ed. New York, Wiley, 2000.

24 Costa-Paiva L, Horovitz AP, Santos AO, et al. Prevalência de osteoporose em mulheres na pósmenopausa e associação com fatores clínicos e reprodutivos. Rev Bras Ginecol Obstet 2003;25:50712.

$25 \mathrm{Wu}$ N, Wang QP, Li H, et al.: Relationships between serum adiponectin, leptin concentrations and bone mineral density, and bone biochemical markers in Chinese women. Clin Chim Acta 2010;411:771-5.

26 Imai Y, Kondoh S, Kouzmenko A, Kato S: Minireview: osteoprotective action of estrogens is mediated by osteoclastic estrogen receptor-alpha. Mol Endocrinol 2010;24:877-85.

27 Waugh EJ, Lam MA, Hawker GA, et al.: Risk factors for low bone mass in healthy 40-60 year old women: a systematic review of the literature. Osteoporos Int 2009;20:1-21 